\title{
Cool Orchard Temperatures or Growing Trees in Containers Can Inhibit Leaf Gas Exchange of Avocado and Mango
}

\author{
Anthony W. Whiley \\ Maroochy Research Station, Centre for Subtropical Fruit, Queensland Horticulture Institute, Department \\ of Primary Industries, P.O. Box 5083 S.C.M.C., Nambour 4560, Australia \\ Christopher Searle \\ Bundaberg Research Station, Queensland Horticulture Institute, Department of Primary Industries, \\ Ashfield Road, Kalkie 4670, Australia \\ Bruce Schaffer ${ }^{1}$ \\ Tropical Research and Education Center, Institute of Food and Agricultural Sciences, University of \\ Florida, 18905 S.W. 280 Street, Homestead, FL 33031

\section{Department of Horticultural Science, University of Natal, Private Bag X01 Scottsville, Pietermaritzburg 3209, South Africa} \\ B. Nigel Wolstenholme
}

AdDitional Index words. Persea americana, Mangifera indica, chlorophyll fluorescence, photoinhibition, photosynthesis, photosynthetic photon flux

\begin{abstract}
Leaf gas exchange of avocado (Persea americana Mill.) and mango (Mangifera indica L.) trees in containers and in an orchard (field-grown trees) was measured over a range of photosynthetic photon fluxes $(\mathrm{PPF})$ and ambient $\mathrm{CO}_{2}$ concentrations $\left(C_{a}\right)$. Net $\mathrm{CO}_{2}$ assimilation $(A)$ and intercellular partial pressure of $\mathrm{CO}_{2}(\mathrm{Ci})$ were determined for all trees in early autumn (noncold-stressed leaves) when minimum daily temperatures were $\geq 14{ }^{\circ} \mathrm{C}$, and for field-grown trees in winter (cold-stressed leaves) when minimum daily temperatures were $\leq 10^{\circ} \mathrm{C}$. Cold-stressed trees of both species had lower maximum $\mathrm{CO}_{2}$ assimilation rates $\left(A_{\max }\right)$, light saturation points $\left(Q_{A}\right), \mathrm{CO}_{2}$ saturation points $\left(C_{a S A T}\right)$ and quantum yields than leaves of noncold-stressed, field-grown trees. The ratio of variable to maximum fluorescence $\left(F_{v} / F_{m}\right)$ was $\approx 50 \%$ lower for leaves of cold-stressed, field-grown trees than for leaves of nonstressed, field-grown trees, indicating chill-induced photoinhibition of leaves had occurred in winter. The data indicate that chill-induced photoinhibition of $A$ and/or sink limitations caused by root restriction in container-grown trees can limit carbon assimilation in avocado and mango trees.
\end{abstract}

Root restriction from growing plants in containers can limit net $\mathrm{CO}_{2}$ assimilation rates $(A)$ via feedback inhibition (Arp, 1991; Schaffer et al., 1996; Thomas and Strain, 1991). For avocado trees, maximum $A\left(A_{\max }\right)$ ranged from $\approx 7$ to $23 \mu \mathrm{mol} \cdot \mathrm{m}^{-2} \cdot \mathrm{s}^{-1}$ with light saturation for $A\left(Q_{A}\right)$ at photosynthetic photon fluxes (PPF) between 400 to $1100 \mu \mathrm{mol} \cdot \mathrm{m}^{-2} \cdot \mathrm{s}^{-1}$ (Bower et al., 1978; Scholefield et al., 1980; Schaffer et al., 1987; Whiley, 1994; Whiley and Schaffer, 1994). Mango $A_{\max }$ was $\approx 6$ to $18 \mu \mathrm{mol} \cdot \mathrm{m}^{-2} \cdot \mathrm{s}^{-1}$ with $Q_{A}$ at $\mathrm{PPF}$ between 300 to $1200 \mu \mathrm{mol} \cdot \mathrm{m}^{-2} \cdot \mathrm{s}^{-1}$ (Chacko et al., 1995; Pongsomboon et al., 1992; Schaffer and Gaye, 1989; Schaffer et al., 1994; Searle et al., 1995). The range of variation in these data was possibly due to measurement or growth conditions, particularly since the lower values were from trees grown in containers, whereas higher values were from field-grown trees.

Received for publication 25 Mar. 1998. Accepted for publication 8 Sept. 1998 Financial support for this study was provided, in part, by the Rural Industries Research and Development Corporation (Australia) under the Climate Change Program. We thank V. Doogan of Biometry, Queensland Department of Primary Industries for assistance with curve fitting and T.S. Rasmussen of Agricultural Chemistry, Queensland Department of Natural Resources for carrying out the starch analyses. B. Schaffer thanks the Rural Industries Research and Development Corporation and the Queensland Department of Primary Industries for financial support while on study-leave at Maroochy Research Station, Centre for Subtropical Fruit, Queensland Horticulture Institute, Nambour, Australia. This article is Florida Agricultural Experiment Station journal series no. R-06241.The cost of publishing this paper was defrayed in part by the payment of page charges. Under postal regulations, this paper therefore must be hereby marked advertisement solely to indicate this fact.

${ }^{1}$ To whom reprint requests should be addressed; e-mail: Bas@gnv.ifas.ufl.edu.
Short-term exposure to temperatures below $10^{\circ} \mathrm{C}$ can cause reversible chilling injury resulting in inhibition of $A$, especially in subtropical and tropical species (Taylor and Rowley, 1971). At high incident PPF, chilling can result in photoinhibitory damage to photosystem 2 (PS II) (Powles, 1984; Smillie et al., 1988) that can be quantified by measuring a decrease in the ratio of variable to maximum chlorophyll fluorescence $\left(F_{v} / F_{m}\right)$ (Björkman, 1987; Demmig and Björkman, 1987).

Avocado (Persea americana Mill.), a polyaxial, terminally flowering, oil-accumulating species (Whiley and Schaffer, 1994) and mango (Mangifera indica L.), a polyaxial, terminally flowering, sugar-accumulating species (Schaffer et al., 1994), are gaining commercial importance worldwide and production is expanding into new environments. Whiley (1994) has classified avocado as a "wintergreen" tree, which more closely resembles the physiology of woody deciduous species. There is comparatively little carbon investment into avocado leaves, which grow rapidly but have a longevity of $<10$ months. In contrast, mango leaves are relatively sclerophyllous with a high investment of carbon during growth. Furthermore, they have drought-resistant mechanisms and are sustained on trees for up to 5 years (Whiley and Schaffer, 1994). Quantifying leaf gas exchange characteristics of these similar evergreen, broad-leaved species may enable the development of models of plant responses to growth conditions (e.g., variation in temperatures and elevated ambient $\mathrm{CO}_{2}$ concentrations), thereby minimizing deleterious effects from suboptimal environments (Schaffer and Andersen, 1994). 
The purpose of this study was to compare photoinhibitory and sink-limitation (root restriction) responses between wintergreen (avocado) and sclerophyllous (mango) leaves of two broad-leaved evergreen trees. To assess potential photoinhibitory damage to leaves, $A$ of field-grown trees was determined when minimum daily (overnight) temperatures were below $10^{\circ} \mathrm{C}$. Root restriction responses were assessed by comparing leaf gas exchange responses of field-grown and container-grown trees.

\section{Materials and Methods}

Plant material. Four- to six-year-old 'Hass' avocado and 'Kensington' (syn. 'Kensington Pride') mango trees were used in this study. Experiments were conducted with field- and containergrown (55-L black polythene containers) trees at Maroochy Research Station, Centre for Subtropical Fruits, Nambour, Queensland, Australia (lat. $=27^{\circ} \mathrm{S}$, elevation $=30 \mathrm{~m}$ above sea level). The orchard soil was a well-drained clay loam ( $\approx 60 \%$ clay fraction) 10 to $16 \mathrm{~m}$ deep and showed no obvious physical limitation to root growth (Whiley, 1994). Trees in containers were grown outdoors under ambient conditions in a potting media of course river sand and peat (1:1). For each species, five single-plant replications were used for leaf gas exchange and leaf starch determinations in studies with both field- and container-grown trees. Plants were irrigated and fertilized according to standard commercial practices (Whiley, 1984; Whiley et al., 1988).

LEAF GAS EXCHANGE. Net $\mathrm{CO}_{2}$ assimilation of leaves and intercellular partial pressure of $\mathrm{CO}_{2}(\mathrm{Ci})$ were determined for the second or third most recently fully expanded leaf of field- and container-grown plants under a range of PPF and ambient $\mathrm{CO}_{2}$ concentrations $\left(C_{a}\right)$. Before measurements, plants were grown under full sunlight (maximum PPF of $\approx 2000 \mu \mathrm{mol} \cdot \mathrm{m}^{-2} \cdot \mathrm{s}^{-1}$ ) and ambient atmospheric $\mathrm{CO}_{2}$ concentrations $\left(\approx 350 \mu \mathrm{mol} \cdot \mathrm{mol}^{-1}\right)$. Determinations of $A$ and $C i$ were made with a CIRAS-1 leaf gas exchange system (PP Systems, Hitchin, Herts., U.K.). Leaf gas exchange was measured when shoot growth on trees was quiescent during early autumn 1994 and minimum daily temperatures were $\geq 14^{\circ} \mathrm{C}$ (noncold-stressed leaves $=\mathrm{NCS}$ ), and again on field-grown trees in winter 1994 when minimum daily (overnight) temperatures were $\leq 10{ }^{\circ} \mathrm{C}$ (cold-stressed leaves $=\mathrm{CS}$ ). Cold-stressed leaves were exposed to 24 nights of temperatures of 8 to $10^{\circ} \mathrm{C}$. Measurements in autumn were made between 0800 to $1030 \mathrm{HR}$ when air temperatures were 25 to $28^{\circ} \mathrm{C}$, whereas winter measurements were between 0900 to $1130 \mathrm{HR}$ when air temperatures were 21 to $24^{\circ} \mathrm{C}$. At each time of the year, vapor pressure deficits were 1.0 to $1.2 \mathrm{kPa}$ when measurements were taken.

To investigate leaf gas exchange responses to incident light flux, PPF was varied nonconsecutively by placing $1 \mathrm{~m}^{2}$ frames covered with polyethylene cloths of different mesh densities, and in different combinations, between the trees and the sun (on a cloudless day) to obtain a range of PPF. The entire canopy was shaded. Frames were placed over the trees for at least 30 min before $A$ determinations to allow sufficient time for leaves to equilibrate to the new light environment. Determinations of $A$ at zero PPF were obtained by wrapping the leaf cuvette in a black cloth and waiting until $\mathrm{CO}_{2}$ evolution from the leaf stabilized (8 to $12 \mathrm{~min}$ ).

Leaf gas exchange responses to $C_{a}$ were made at saturating PPF (previously determined as $>400 \mu \mathrm{mol} \cdot \mathrm{m}^{-2} \cdot \mathrm{s}^{-1}$ ). A range of $C_{a}$ concentrations in the leaf cuvette was achieved using the CIRAS1 gas exchange system, which allows variable $\mathrm{CO}_{2}$ concentrations to be delivered to the cuvette from a supplemented $\mathrm{CO}_{2}$ source. For below ambient concentrations, the air stream was passed through a series of $\mathrm{CO}_{2}$ scrubbers (cylinders containing soda lime) before entering the cuvette. Determinations of $A$ and $C i$ were made when $\mathrm{CO}_{2}$ flux in the cuvette had equilibrated $(\approx 3$ to 5 min after placing the leaf in the cuvette after $C_{a}$ was changed).

Chlorophyll Fluorescence. To quantify chilling injury to PS II, chlorophyll fluorescence of leaves on field-grown trees was measured on four to five leaves per tree at the same time as leaf gas exchange determinations were made using a BioMonitor Stress Meter (BioMonitor SCI, Umeå, Sweden). Cuvettes were attached to each side of the leaf midrib for $30 \mathrm{~min}$ between 0900 and 1000 HR. Chlorophyll fluorescence was then determined on the adaxial leaf surface after two seconds of irradiation with $600 \mu \mathrm{mol} \cdot \mathrm{m}^{-2} \cdot \mathrm{s}^{-}$ ${ }^{1}$ of blue light $(320$ to $550 \mathrm{~nm})$. Variable fluorescence $\left(F_{v}\right)$ was calculated as $F_{v}=F_{m}-F_{o}$, where $F_{o}$ is the initial constant yield fluorescence and $F_{m}$ is the maximum fluorescence recorded (Öquist and Wass, 1988). The ratio of $F_{\downarrow} / F_{m}$ was calculated as an indication of photoinhibitory damage to PS II (Björkman, 1987; Demmig and Björkman, 1987).

LEAF STARCH. Starch concentrations in avocado and mango trees were determined on the second or third, fully expanded leaf from the most recently matured shoots on each tree. Fifteen leaves were collected from each of five trees from the different treatments between 0800 and 1030 HR and subsequently placed in a convection oven at $60{ }^{\circ} \mathrm{C}$ and dried to constant mass. Dried samples were ground at 100 mesh in a cyclone grinder (UDY Corporation, Fort Collins, Colo.) and stored in air-tight containers. Starch was determined by a two-stage enzymatic hydrolysis of starch to glucose and the concentration measured colorimetrically with a coupled glucose oxidase/peroxidase/chromogen system as described by Rasmussen and Henry (1990).

DATA ANALYSES. Data were analyzed by regression analysis (Table Curve, SPSS, Inc., Chicago). Light and $\mathrm{CO}_{2}$ saturation points for $A$ were calculated as $90 \%$ of $A_{\max }$ (Osman and Milthorpe, 1971). Quantum yield $(\varnothing)$ was calculated as the slope of the linear portion of the regression line of $A$ vs. incident PPF (Syvertsen, 1984). Significant differences in $\varnothing$ between field- and containergrown plants of each species were determined by testing for homogeneity of slopes (SAS Institute, Cary, N.C.).

\section{Results}

Leaf gas eXchange Responses to InCIDENT PPF. Net $\mathrm{CO}_{2}$ assimilation increased and $\mathrm{Ci}$ decreased asymptotically in response to increasing PPF for both species (Figs. 1 and 2). For both species, $A_{\max }$ was greater for field- than for container-grown trees and greater for NCS than for CS leaves (Table 1). For avocado, the light saturation point for $A\left(Q_{A}\right)$ was $\approx 1270 \mu \mathrm{mol} \cdot \mathrm{m}^{-2} \cdot \mathrm{s}^{-1}$ for NCS, field-grown trees, compared to $\approx 1040 \mu \mathrm{mol} \cdot \mathrm{m}^{-2} \cdot \mathrm{s}^{-1}$ for CS, fieldgrown trees and $\approx 586 \mu \mathrm{mol} \cdot \mathrm{m}^{-2} \cdot \mathrm{s}^{-1}$ for container-grown trees (Table $1)$. The light compensation point $\left(Q_{o}\right)$ for field-grown avocado was lower for NCS $\left(30 \mu \mathrm{mol} \cdot \mathrm{m}^{-2} \cdot \mathrm{s}^{-1}\right)$ than for CS $\left(50 \mu \mathrm{mol} \cdot \mathrm{m}^{-2} \cdot \mathrm{s}^{-1}\right)$ trees. For container-grown trees, $Q_{o}$ was $38 \mu \mathrm{mol} \cdot \mathrm{m}^{-2} \cdot \mathrm{s}^{-1}$. Cold stress reduced $\varnothing$ of field-grown trees from $0.055 \mu \mathrm{mol} \mathrm{CO} 2 / \mathrm{mol}$ quanta in fall to $0.034 \mu \mathrm{mol} \mathrm{CO} \mathrm{CO}_{2} / \mathrm{mol}$ quanta following exposure to overnight minimums of $\leq 10.0{ }^{\circ} \mathrm{C}$, whereas the $\varnothing$ for containergrown trees was further reduced to $0.021 \mu \mathrm{mol} \mathrm{CO} / \mathrm{mol}$ quanta. Quantum yield was higher in NCS than in CS leaves $(P \leq 0.01)$ and in field- compared with container-grown avocado trees $(P \leq 0.05)$.

For container-and field-grown avocado trees, $C i$ initially declined rapidly and then leveled off at PPF above $500 \mu \mathrm{mol} \cdot \mathrm{m}^{-2} \cdot \mathrm{s}^{-1}$ (Fig. 1b). To quantify the effects of PPF on $\mathrm{Ci}$, the $Q_{1 / 2}$, representing the PPF at which $C i$ is reduced by $50 \%$, was calculated from $Q_{1 / 2}=\ln (0.5) /$ $-\mathrm{k}$, where $k$ is the third constant in the standard decay curve fitted to the data (adapted from Jones, 1992). 


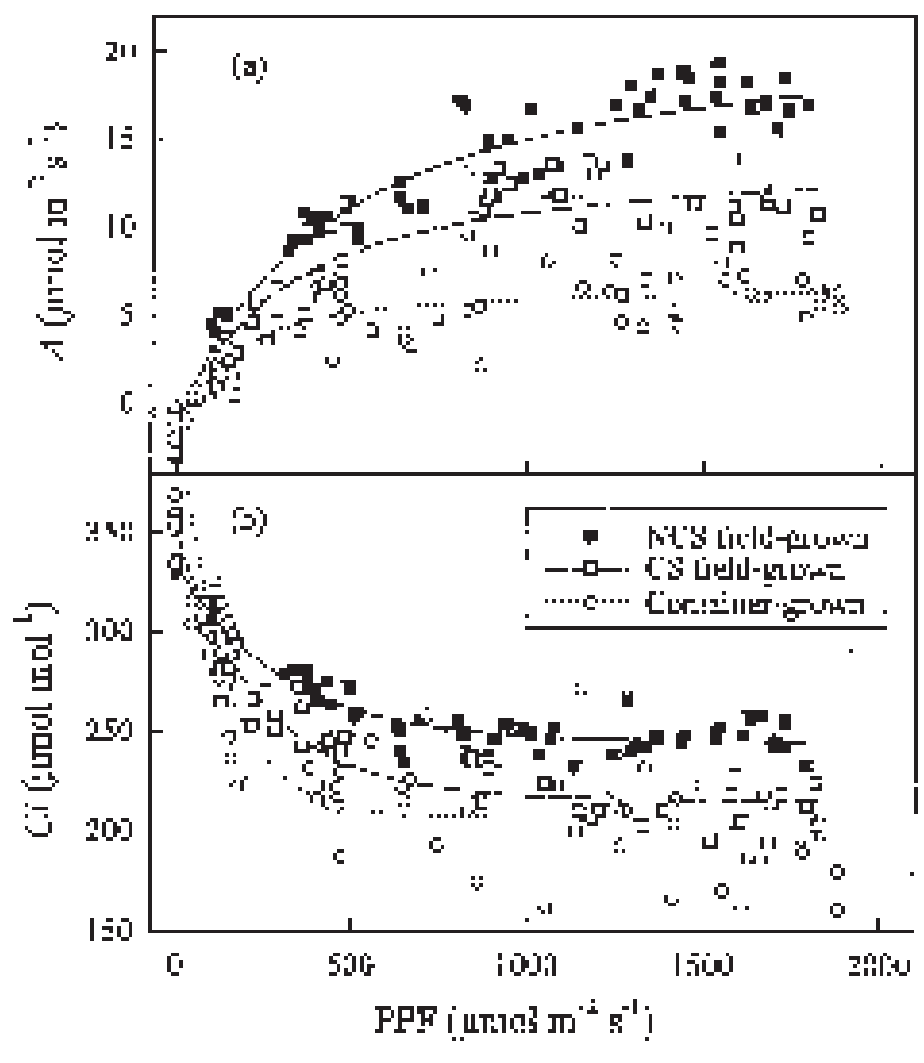

Fig. 1. Net $\mathrm{CO}_{2}$ assimilation $(A)$ and intercellular partial pressure of $\mathrm{CO}_{2}(\mathrm{Ci})$ responses of field- and container-grown avocado trees ('Hass') to varying photosynthetic photon fluxes (PPF). The regression line for $A$ (a) of noncoldstressed (NCS), field-grown trees is represented by $\mathrm{y}=22.08((-30.67+\mathrm{x}) /(427.43$ $+\mathrm{x})), r^{2}=0.94$; cold stressed $(\mathrm{CS})$, field-grown trees is represented by $\mathrm{y}=14.17((-$ $46.72+\mathrm{x}) /(250.05+\mathrm{x})), r^{2}=0.86$; and container-grown trees is represented by y $=7.16((-38.366+\mathrm{x}) /(172.12+\mathrm{x})), r^{2}=0.84$. The regression line for $\mathrm{Ci}(\mathbf{b})$ for NCS, field-grown trees is represented by y $=244.65+90.2 \exp (-0.0034 \mathrm{x}), r^{2}=0.94 ; \mathrm{CS}$, field-grown trees by $\mathrm{y}=215.28+135.52 \exp (-0.0041 \mathrm{x}), r^{2}=0.92$; and containergrown trees by $\mathrm{y}=203.70+171.39 \exp (-0.0056 \mathrm{x}), r^{2}=0.87$.

The $Q_{1 / 2}$ for NCS, field-grown avocado trees was $204 \mu \mathrm{mol} \cdot \mathrm{m}^{-2} \cdot \mathrm{s}^{-1}$ compared to $169 \mu \mathrm{mol} \cdot \mathrm{m}^{-2} \cdot \mathrm{s}^{-1}$ for CS, field-grown trees and 123 $\mu \mathrm{mol} \cdot \mathrm{m}^{-2} \cdot \mathrm{s}^{-1}$ for container-grown trees, indicating that leaves from $\mathrm{CS}$, field-grown and container-grown trees had a higher light requirement than leaves of NCS, field-grown trees to reduce $C i$ by one-half.

For NCS, field-grown mango trees, $Q_{A}$ was $\approx 1284 \mu \mathrm{mol} \cdot \mathrm{m}^{-2} \cdot \mathrm{s}^{-1}$, compared to $\approx 1180 \mu \mathrm{mol} \cdot \mathrm{m}^{-2} \cdot \mathrm{s}^{-1}$ for CS, field-grown trees and $\approx 563$ $\mu \mathrm{mol} \cdot \mathrm{m}^{-2} \cdot \mathrm{s}^{-1}$ for container-grown trees (Table 1 ). The $Q_{o}$ for fieldgrown mango was 29 and $66 \mu \mathrm{mol} \cdot \mathrm{m}^{-2} \cdot \mathrm{s}^{-1}$ for NCS and CS leaves, respectively. For container-grown trees, $Q_{o}$ was $47 \mu \mathrm{mol} \cdot \mathrm{m}^{-2} \cdot \mathrm{s}^{-1}$. Lower temperatures reduced $\varnothing$ of field-grown trees from 0.042 $\mu \mathrm{mol} \mathrm{CO}_{2} / \mu \mathrm{mol}$ quanta in fall to $0.025 \mu \mathrm{mol} \mathrm{CO} / \mu \mathrm{mol}$ quanta for CS leaves in winter, whereas the $\varnothing$ for container-grown trees was 0.033 (Table 1). Quantum yield was significantly greater between NCS and CS leaves $(P \leq 0.01)$ as well as between NCS, field- and container-grown mango trees $(P \leq 0.05)$.

The response of mango $C i$ to PPF was similar to that of avocado trees: $C i$ decreased as PPF increased but leveled off as $A_{\max }$ was reached (Fig. 2b). The $Q_{1 / 2}$ for leaves from NCS, field-grown mango trees was $223 \mu \mathrm{mol} \cdot \mathrm{m}^{-2} \cdot \mathrm{s}^{-1}$ compared to $74 \mu \mathrm{mol} \cdot \mathrm{m}^{-2} \cdot \mathrm{s}^{-1}$ for $\mathrm{CS}$, field- and $161 \mu \mathrm{mol} \cdot \mathrm{m}^{-2} \cdot \mathrm{s}^{-1}$ for container-grown trees.

LEAF GAS EXChANGE RESPONSES TO AMBIENT PARTIAL PRESSURE OF $\mathrm{CO}_{2}$. For container- and field-grown avocado and mango trees, $A$ increased asymptotically as $C_{a}$ increased, whereas there was a linear relationship between $C i$ and $C_{a}$ (Figs. 3 and 4). The ambient $\mathrm{CO}_{2}$ concentration at which $A_{\max }$ occurred $\left(C_{a S A T}\right)$ in avocado was highest for leaves from NCS, field-grown trees $\left(1473 \mu \mathrm{mol} \cdot \mathrm{mol}^{-1}\right)$ compared with leaves from CS, field- $\left(1357 \mu \mathrm{mol} \cdot \mathrm{mol}^{-1}\right)$ and container-grown $\left(1261 \mu \mathrm{mol} \cdot \mathrm{mol}^{-1}\right)$ trees (Table 2$)$. The saturated $\mathrm{CO}_{2}$ assimilation rate $\left(A_{\max C a}\right)$ was also lower for leaves from CS, field- $\left(A_{\max C a}=34.9 \mu \mathrm{mol} \cdot \mathrm{m}^{-2} \cdot \mathrm{s}^{-1}\right)$ and container-grown $\left(A_{\operatorname{maxCa}}=\right.$ $\left.26.1 \mu \mathrm{mol} \cdot \mathrm{m}^{-2} \cdot \mathrm{s}^{-1}\right)$ avocado trees than for NCS, field-grown avocado trees $\left(A_{\max C a}=50.6 \mu \mathrm{mol} \cdot \mathrm{m}^{-2} \cdot \mathrm{s}^{-1}\right)$ (Table 2$)$.

For leaves of NCS, field-grown mango, $C_{a S A T}$ was 1113 compared to $871 \mu \mathrm{mol} \cdot \mathrm{mol}^{-1}$ for container-grown and $636 \mu \mathrm{mol} \cdot \mathrm{mol}^{-1}$ for $\mathrm{CS}$, field-grown trees (Table 2). At $C_{a}$ levels $>600 \mu \mathrm{mol} \cdot \mathrm{mol}^{-1}, A$ tended to level off for field- and container-grown trees (Fig. 4a) while $A_{\max C a}$ was higher for NCS, field- $\left(30.3 \mu \mathrm{mol} \cdot \mathrm{m}^{-2} \cdot \mathrm{s}^{-1}\right)$ than for container-grown $\left(21.5 \mu \mathrm{mol} \cdot \mathrm{m}^{-2} \cdot \mathrm{s}^{-1}\right)$ and $\mathrm{CS}$, field-grown (8.3 $\mu \mathrm{mol} \cdot \mathrm{m}^{-2} \cdot \mathrm{s}^{-1}$ ) mango trees (Table 2 ). For container- and fieldgrown avocado and mango trees, $C i$ increased linearly as $C_{a}$ increased indicating that $\mathrm{CO}_{2}$ concentration was not limiting $A$ (Figs. $3 b$ and $4 b$ ).

Chlorophyll FluORESCENCE. The $F_{\sqrt{ }} / F_{m}$ ratios for leaves of NCS, field-grown trees were $0.81 \pm 0.02$ and $0.80 \pm 0.03$, for avocado and mango, respectively (Table 2). During winter, the $F_{v} / F_{m}$ ratio declined to $0.41 \pm 0.03$ for avocado and $0.45 \pm 0.03$ for mango.

LEAF STARCH. Leaf starch concentrations (leaf dry weight basis) measured in NCS, field-grown avocados $\left(17.4 \pm 1.4 \mathrm{mg} \cdot \mathrm{g}^{-1}\right)$ were less than those for CS, field- $\left(23.4 \pm 4.0 \mathrm{mg} \cdot \mathrm{g}^{-1}\right)$ and container-

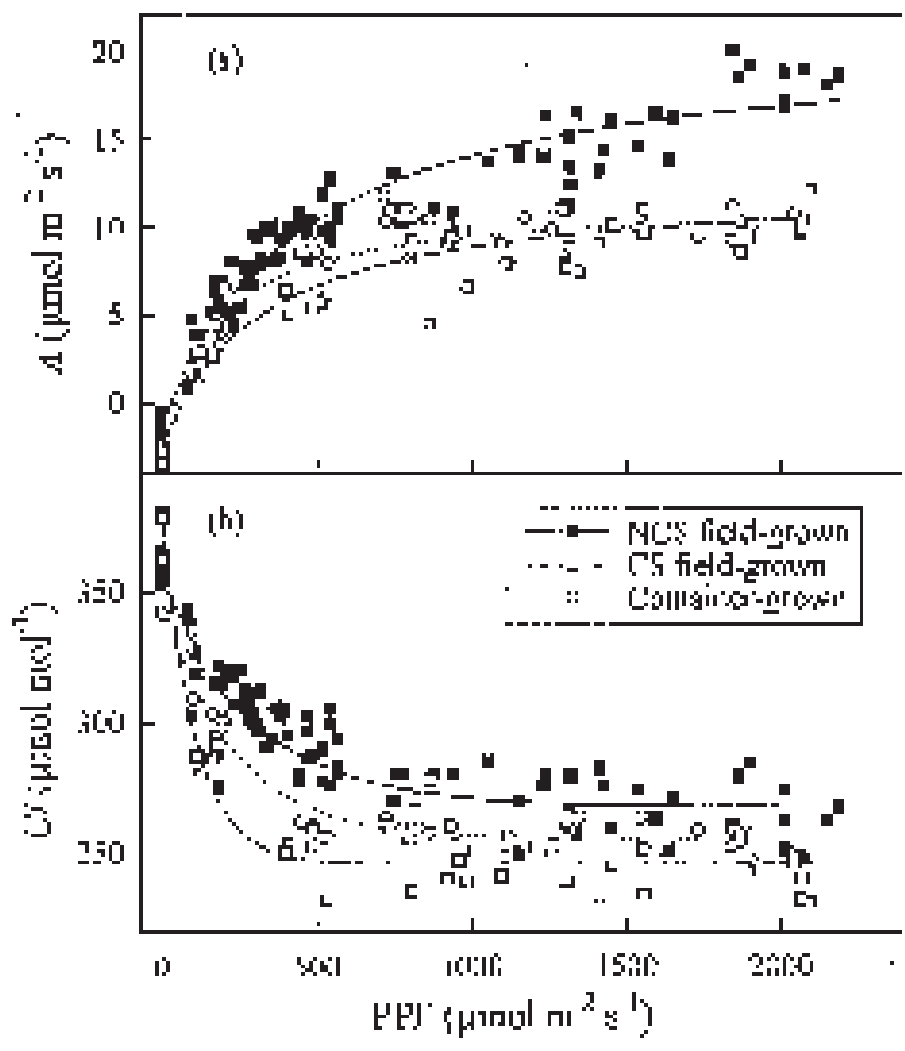

Fig. 2. Net $\mathrm{CO}_{2}$ assimilation $(A)$ and intercellular partial pressure of $\mathrm{CO}_{2}(\mathrm{Ci})$ responses of field- and container-grown mango trees ('Kensington') to varying photosynthetic photon fluxes (PPF). The regression line for $A$ (a) of noncoldstressed (NCS), field-grown trees is represented by $\mathrm{y}=20.94((-28.97+\mathrm{x}) /$ $(448.27+\mathrm{x})), r^{2}=0.94$; cold stressed $(\mathrm{CS})$, field-grown trees by $\mathrm{y}=12.42((-66.26$ $+\mathrm{x}) /(309.02+\mathrm{x})), r^{2}=0.91$; and container-grown trees by $\mathrm{y}=11.40((-45.97+\mathrm{x}) /$ $(152.39+\mathrm{x})), r^{2}=0.91$. The regression line for $\mathrm{Ci}(\mathbf{b})$ for NCS, field-grown trees is represented by $\mathrm{y}=267.27+87.38 \exp (-0.0031 \mathrm{x}), r^{2}=0.97$; for CS, field-grown trees by $\mathrm{y}=245.57+133.54 \exp (-0.0094 \mathrm{x}), r^{2}=0.93$; and container-grown trees by $\mathrm{y}=255.0+90.46 \exp (-0.0043 \mathrm{x}), r^{2}=0.95$. 
Table 1. The effect of growing conditions on light saturation of $\mathrm{CO}_{2}$ assimilation $\left(Q_{A}\right)$, the compensation point for $\mathrm{CO}_{2}$ assimilation $\left(Q_{o}\right)$, the maximum rate of $\mathrm{CO}_{2}$ assimilation $\left(A_{\max }\right)$ and the quantum efficiency $(\varnothing)$ of avocado and mango trees. Values were estimated from the regression models presented in Figs. 1 and 2, which were based on pooled data from one leaf of each of five trees.

\begin{tabular}{|c|c|c|c|c|}
\hline Treatment & $\begin{array}{c}Q_{A} \\
\left(\mu \mathrm{mol} \cdot \mathrm{m}^{-2} \cdot \mathrm{s}^{-1}\right)\end{array}$ & $\begin{array}{c}Q_{o} \\
\left(\mu \mathrm{mol} \cdot \mathrm{m}^{-2} \cdot \mathrm{s}^{-1}\right)\end{array}$ & $\begin{array}{c}A_{\max } \\
\left(\mu \mathrm{mol} \cdot \mathrm{m}^{-2} \cdot \mathrm{s}^{-1}\right)\end{array}$ & $\begin{array}{c}\varnothing \\
(\mu \mathrm{mol} \mathrm{CO} / \mu \mathrm{mol} \text { quanta })\end{array}$ \\
\hline \multicolumn{5}{|l|}{ Avocado } \\
\hline NCS field-grown & 1270 & 30 & 19.0 & $0.055 \mathrm{a}^{\mathrm{z}}$ \\
\hline CS field-grown & 1040 & 50 & 10.9 & $0.034 \mathrm{~b}$ \\
\hline Container-grown & 586 & 38 & 5.2 & $0.021 \mathrm{c}$ \\
\hline \multicolumn{5}{|l|}{ Mango } \\
\hline NCS field-grown & 1284 & 29 & 15.2 & $0.042 \mathrm{a}^{\mathrm{z}}$ \\
\hline CS field-grown & 1180 & 66 & 8.8 & $0.025 b$ \\
\hline Container-grown & 563 & 47 & 8.1 & $0.033 \mathrm{c}$ \\
\hline
\end{tabular}

${ }^{\mathrm{z}}$ Means followed by different letters for each species indicate significant difference $(P \leq 0.05)$ according to a test for homogeneity of slopes.

grown trees $\left(28.0 \pm 2.6 \mathrm{mg} \cdot \mathrm{g}^{-1}\right)$ (Table 2$)$. There was also a similar response for leaf starch concentrations in mango with levels in NCS, field-grown trees at $14.0 \pm 0.30 \mathrm{mg} \cdot \mathrm{g}^{-1}$ dry weight compared with $25.4 \pm 1.4 \mathrm{mg} \cdot \mathrm{g}^{-1}$ for leaves of CS, field-grown and $32.2 \pm 1.8$ $\mathrm{mg} \cdot \mathrm{g}^{-1}$ for container-grown trees.

\section{Discussion}

The lower $A$ of container-grown than of field-grown plants may have been due to a carbon sink limitation as a result of root restriction in containers. Although the root mass was not determined for container- and field-grown plants in this study, previous experiments have indicated that similar-aged avocado and mango plants maintained in similar-size containers for the time period of this study become pot bound (A.W. Whiley and B. Schaffer, unpublished data). Cold stress (exposing trees to $24 \mathrm{~d}$ of 8 to $10^{\circ} \mathrm{C}$ temperatures) also limited $A$ of avocado and mango in this study. Below saturating PPF, $\mathrm{Ci}$ decreased linearly as PPF increased, indicating unrestricted $\mathrm{CO}_{2}$ diffusion through stomata. Thus, the reductions in $A$ were apparently due to reduced carboxylation by the plant rather than a reduction in $\mathrm{CO}_{2}$ diffusion through the mesophyll tissues. However, at $Q_{A}, C i$ remained relatively constant indicating a point of equilibrium between PPF and the diffusion of $\mathrm{CO}_{2}$ to fixation sites. Under noncold-stressed conditions, $\varnothing$ for avocado and mango trees approximated the normal range of $\varnothing$ for $C_{3}$ species (Ehleringer and Björkman, 1977). The lower $\varnothing$ for CS, field- and container-grown trees than for NCS trees indicated a reduced quantum-use efficiency at low incident PPF as a result of both source and sink limitations to $A$.

The $Q_{A}$ observed in this study for NCS, field-grown avocado $\left(Q_{A} \approx 1270 \mu \mathrm{mol} \cdot \mathrm{m}^{-2} \cdot \mathrm{s}^{-1}\right)$ and mango $\left(Q_{A} \approx 1284 \mu \mathrm{mol} \cdot \mathrm{m}^{-2} \cdot \mathrm{s}^{-1}\right)$ were considerably higher than previously reported rates for these crops (Bower et al., 1978; Scholefield et al., 1980; Schaffer and Gaye, 1989). The higher $Q_{1 / 2}$ for NCS, field-grown avocado trees than for the CS, field-grown trees and container-grown trees, indicates that leaves of CS, field-grown and container-grown trees had a higher light requirement than leaves of NCS, field-grown trees to reduce $C i$ by one-half. Thus, the $Q_{A}$ of NCS leaves would be higher than that of leaves from CS, field- and container-grown trees (assuming stomatal conductance is nonlimiting under wellwatered conditions), thereby supporting the data presented in Fig. 1. The $A_{\max }$ that we observed for NCS, field-grown trees of each species was much greater than data previously published. For field-grown avocado in Florida, $A_{\max }$ was reported to be 7 to $10 \mu \mathrm{mol} \cdot \mathrm{m}^{-2} \cdot \mathrm{s}^{-1}($ Schaffer et al., 1987, 1991) compared to $19.0 \mu \mathrm{mol} \cdot \mathrm{m}^{-2} \cdot \mathrm{s}^{-1}$ observed for fieldgrown trees in this study. Similarly, $A_{\max }$ for field-grown mango in Florida was $6.2 \mu \mathrm{mol} \cdot \mathrm{m}^{-2} \cdot \mathrm{s}^{-1}$ (Schaffer and Gaye, 1989) compared to $15.2 \mu \mathrm{mol} \cdot \mathrm{m}^{-2} \cdot \mathrm{s}^{-1}$ determined in our study for nonstressed fieldgrown trees in Australia. In contrast, the $A_{\max }$ and $Q_{A}$ for containergrown avocado $\left(5.2 \mu \mathrm{mol} \cdot \mathrm{m}^{-2} \cdot \mathrm{s}^{-1} ; 586 \mu \mathrm{mol} \cdot \mathrm{m}^{-2} \cdot \mathrm{s}^{-1}\right)$ and mango $(8.1$ $\left.\mu \mathrm{mol} \cdot \mathrm{m}^{-2} \cdot \mathrm{s}^{-1} ; 563 \mu \mathrm{mol} \cdot \mathrm{m}^{-2} \cdot \mathrm{s}^{-1}\right)$ were similar to those previously reported for trees grown in containers (Bower et al., 1978; Scholefield et al., 1980; Schaffer et al., 1987; Schaffer and Gaye, 1989; Larson et al., 1992; Pongsomboon et al., 1992). For single leaves of container-grown avocado, Bower et al. (1978) and Scholefield et al. (1980) have reported $Q_{A}$ to be between 400 to 660 $\mu \mathrm{mol} \cdot \mathrm{m}^{-2} \cdot \mathrm{s}^{-1}$ with an $A_{\max }$ of $\approx 7.0 \mu \mathrm{mol} \cdot \mathrm{m}^{-2} \cdot \mathrm{s}^{-1}$, while for mango a $Q_{A}$ of 350 to $400 \mu \mathrm{mol} \cdot \mathrm{m}^{-2} \cdot \mathrm{s}^{-1}$ with an $A_{\max }$ of 6 to $7 \mu \mathrm{mol} \cdot \mathrm{m}^{-2} \cdot \mathrm{s}^{-1}$ has

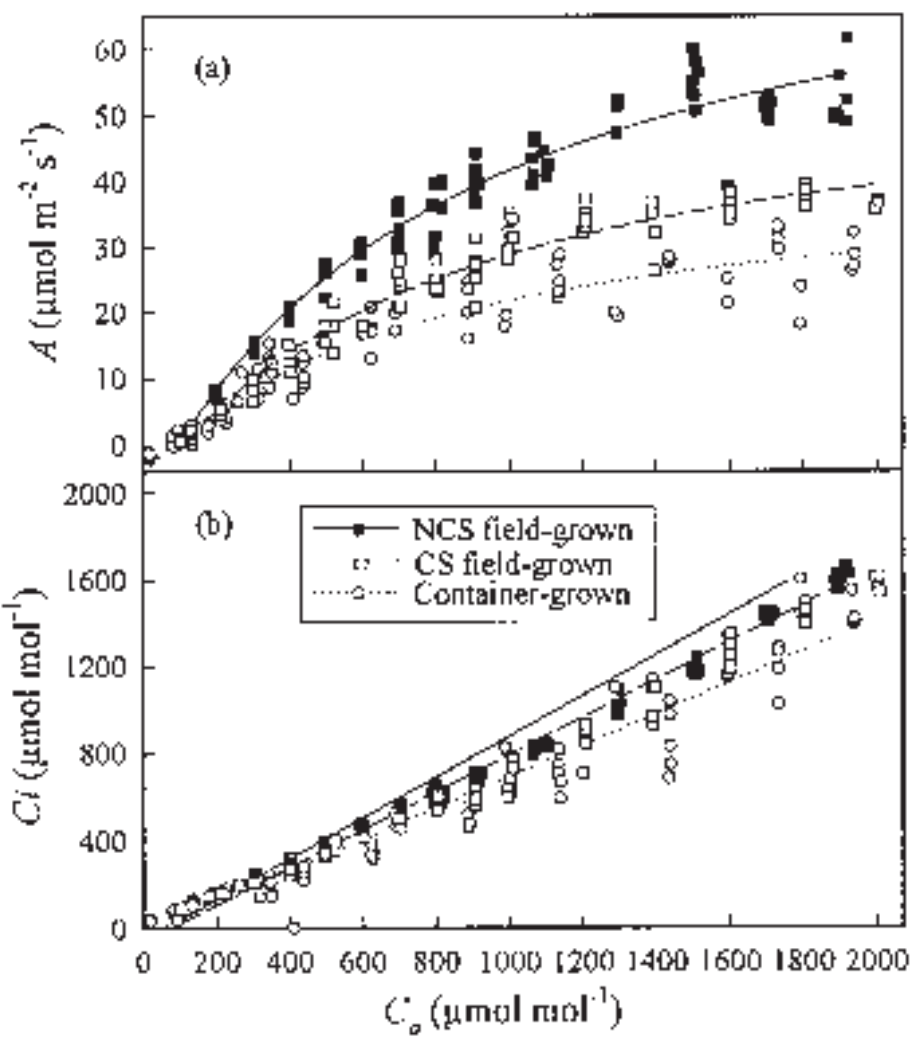

Fig. 3. Net $\mathrm{CO}_{2}$ assimilation $(A)$ and intercellular partial pressure of $\mathrm{CO}_{2}(\mathrm{Ci})$ responses of field- and container-grown avocado ('Hass') trees to varying ambient $\mathrm{CO}_{2}$ partial pressures $\left(C_{a}\right)$. The regression line for $A$ of noncold-stressed (NCS), field-grown trees (a) is represented by $\mathrm{y}=85.49((-96.72+\mathrm{x}) /(852.75+\mathrm{x})), r^{2}=$ 0.96; cold-stressed (CS), field-grown trees by $\mathrm{y}=58.54((-110.10+\mathrm{x}) /(805.77+$ $\mathrm{x})), r^{2}=0.96$; and container-grown trees by $\mathrm{y}=42.73((-78.62+\mathrm{x}) /(801.42+\mathrm{x}))$, $r^{2}=0.92$. The regression line for $\mathrm{Ci}(\mathbf{b})$ of NCS, field-grown trees is represented by $\mathrm{y}=-0.851 \mathrm{x}-47.590, r^{2}=0.99$; for CS, field-grown trees by $\mathrm{y}=0.812 \mathrm{x}-60.877$, $r^{2}=0.98$; and container-grown trees by $\mathrm{y}=0.723 \mathrm{x}-27.95, r^{2}=0.95$. 

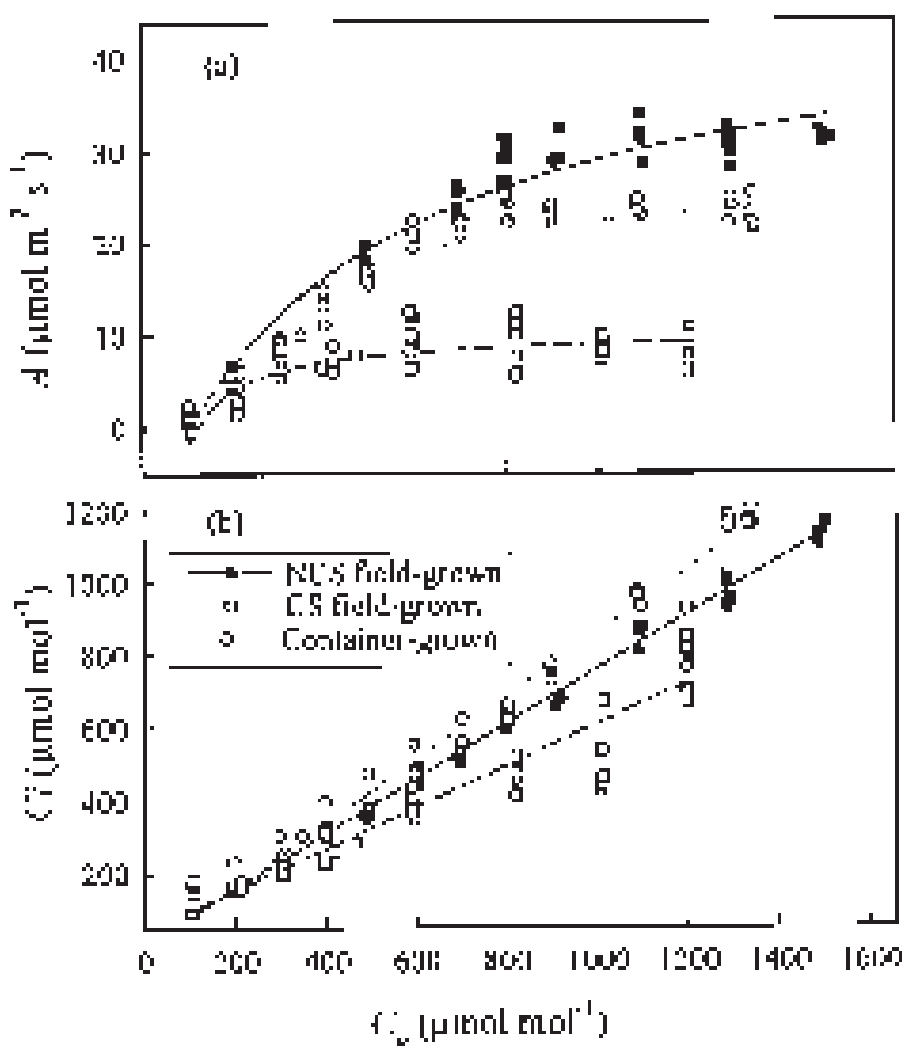

Fig. 4. Net $\mathrm{CO}_{2}$ assimilation $(A)$ and intercellular partial pressure of $\mathrm{CO}_{2}(\mathrm{Ci})$ responses of field- and container-grown mango ('Kensington') trees to varying ambient $\mathrm{CO}_{2}$ partial pressures $\left(C_{a}\right)$. The regression line for $A$ (a) for noncoldstressed (NCS), field-grown trees is represented by $\mathrm{y}=47.38((-105.0+\mathrm{x}) /(462.4$ $+\mathrm{x})), r^{2}=0.95$; cold stressed (CS), field-grown trees by $\mathrm{y}=10.24-1247.52 / \mathrm{x}$, $r^{2}=0.73$; and container-grown trees by $\mathrm{y}=33.61-357.84 / \mathrm{x}^{0.5}, r^{2}=0.91$. The regression line for $\mathrm{Ci}$ (b) for NCS, field-grown trees is represented by y $=9.026$ $+0.753 \mathrm{x}, r^{2}=0.99 ; \mathrm{CS}$, field-grown trees by $\mathrm{y}=40.67+0.568 \mathrm{x}, r^{2}=0.92$; and container-grown trees by $\mathrm{y}=-10.857+0.872 \mathrm{x}, r^{2}=0.99$.

been observed (Schaffer and Gaye, 1989; Larson et al., 1992; Pongsomboon et al., 1992). Hence, for avocado and mango trees grown in containers there is relative consistency between the reported values of $Q_{A}$ and $A_{\max }$.

The relatively low $A_{\max }$ rates that we observed for containergrown compared to field-grown trees may be attributed to containers restricting the root sink, thus causing the photoassimilate supply to exceed the capacity of demand (i.e., end-product inhibition of photosynthesis) (Schaffer et al., 1994). This is supported by the increased concentrations of leaf starch for both crops growing in containers ( $160 \%$ to $230 \%$ higher in container-grown compared with NCS, field-grown trees). Increased leaf starch in avocado accompanied by a reduction in $A_{\max }$ was reported by Schaffer et al. (1987) who concluded that the latter occurred as a result of feedback inhibition. For other species, reduced $A$ of containergrown plants as a result of root restriction has been attributed to end-product inhibition of photosynthesis caused by root restriction (Arp, 1991; Thomas and Strain, 1991). Although only starch was measured in this study, other nonstructural carbohydrates such as glucose and hexoses may have accumulated in the leaves as a result of sink (root) restriction. It has been recently proposed that accumulation of these end-products, particularly hexoses, in the leaves may repress genes that code for rubisco, resulting in feedback inhibition of $A$ (Drake et al., 1997; Koch, 1996; Stitt, 1991). The hard, oolitic limestone soils of Florida can severely limit root growth, thus restricting the development of this sink (Crane et al., 1994; Schaffer et al., 1994). Thus, the relatively low $A_{\max }$ previously observed for field-grown trees in Florida may also be the result of end-product inhibition of photosynthesis.

The lower $Q_{A}$ and $A_{\max }$ of field-grown avocado and mango trees that were determined for CS compared to NCS trees, were most likely due to photoinhibition of $A$ as a result of low temperatures interacting with high incident PPF (Groom et al., 1991). Limited exposure of tropical and subtropical species to below $10^{\circ} \mathrm{C}$ can result in reversible inhibition of photosynthesis (Taylor and Rowley, 1971). The $F_{v} / F_{m}$ ratios for leaves of NCS, field-grown trees were $0.81 \pm 0.02$ and $0.80 \pm 0.03$, for avocado and mango, respectively (Table 2), indicating that the photosynthetic processes were functioning normally in autumn (Öquist and Wass, 1988). The $F_{v} / F_{m}$ ratios for avocado and mango trees were lower in winter when minimum daily temperatures decreased below $10^{\circ} \mathrm{C}$ compared to early fall when chilling did not occur. Leaves also visibly appeared chlorotic following exposure to winter temperatures suggesting photooxidation of the chlorophyll. The lower $F_{v} / F_{m}$ ratios indicated a reduced photochemical conversion efficiency of PS II (Krause, 1988), which can be an effect of photoinhibition at chilling temperatures (Groom et al., 1991). Photoinhibition from chilling injury can reduce $\varnothing$ and $Q_{A}$ (Powles et al., 1983) as we observed for avocado and mango during the winter measurement period. For both species, reduced $A$ in winter may also have been partially a result of feedback inhibition. Since the canopy of avocado and mango trees is relatively quiescent during winter, the resultant reduction in sink strength promotes an increase in starch concentrations in leaves (Whiley, 1994). In our study, leaf starch

Table 2. The effect of growing conditions on $\mathrm{CO}_{2}$ saturation of $\mathrm{CO}_{2}$ assimilation $\left(C_{a S A T}\right)$, the maximum rate of $\mathrm{CO}_{2}$ assimilation at saturating partial pressures of $\mathrm{CO}_{2}\left(A_{\max C a}\right)$, chlorophyll fluorescence $\left(F_{v} / F_{m}\right)$ and leaf starch concentrations on a dry weight basis. Values of $C_{a S A T}$ and $A_{m a x C a}$ were estimated from the regression models presented in Figs. 3 and 4 which were based on pooled data from one leaf of each of five trees. $F_{v} / F_{m}$ and leaf starch data are mean values \pm standard errors $(n=5)$.

\begin{tabular}{|c|c|c|c|c|}
\hline Treatment & $\begin{array}{c}C_{a S A T} \\
\left(\mu \mathrm{mol} \cdot \mathrm{mol}^{-1}\right)\end{array}$ & $\begin{array}{c}A_{\operatorname{maxCa}} \\
\left(\mu \mathrm{mol} \cdot \mathrm{m}^{-2} \cdot \mathrm{s}^{-1}\right)\end{array}$ & $F_{v} / F_{m}$ & $\begin{array}{c}\text { Leaf starch concn } \\
\left(\mathrm{mg} \cdot \mathrm{g}^{-1}\right)\end{array}$ \\
\hline \multicolumn{5}{|l|}{ Avocado } \\
\hline NCS field-grown & 1473 & 50.6 & $0.81 \pm 0.02$ & $17.4 \pm 0.14$ \\
\hline CS field-grown & 1357 & 34.9 & $0.41 \pm 0.03$ & $23.4 \pm 0.20$ \\
\hline Container-grown & 1261 & 26.1 & --- & $28.0 \pm 0.26$ \\
\hline \multicolumn{5}{|l|}{ Mango } \\
\hline NCS field-grown & 1113 & 30.3 & $0.80 \pm 0.03$ & $14.0 \pm 0.03$ \\
\hline CS field-grown & 636 & 8.3 & $0.45 \pm 0.03$ & $25.4 \pm 0.14$ \\
\hline Container-grown & 871 & 21.5 & --- & $32.2 \pm 0.18$ \\
\hline
\end{tabular}


concentrations in CS, field-grown avocado and mango trees were higher than in NCS, field-grown trees, thereby creating some doubt about relative importance of photoinhibition to the reduction of $A$. Further investigations to isolate the effect of cold stress from root restriction and elevated carbohydrate concentrations are required to clarify the situation.

The positive linear correlation between $C i$ and $C_{a}$ implied that $\mathrm{CO}_{2}$ diffusion through the mesophyll tissue was never limiting $A$. Leaves of NCS, field-grown trees had higher $C_{a S A T}$ than leaves from $\mathrm{CS}$, field-grown and container-grown trees. The carbon sourcesink balance is a major factor in determining the response of plants to elevated $\mathrm{CO}_{2}$ (Arp, 1991). For example, reduced $A$ of bean plants in a $\mathrm{CO}_{2}$-enriched environment has been positively correlated with the carbon source-sink ratio (Peet, 1984). Thus, the lower $C_{a S A T}$ for container-grown than for field-grown avocado and mango presumably was from an increased source-sink ratio due to root restriction. For field-grown trees in winter, either photoinhibition, feedback inhibition of $A$ due to the lack of vegetative growth, or their combined effects may have resulted in a downward regulation of $A$ and lower $C_{a S A T}$. However, $C_{a S A T}$ can also be reduced through source-imposed limitations to $A$ such as a reduction of incident PPF (Ehret and Joliffe, 1985).

When comparing the relative efficiency and capacity of $A$ between the two species in this study, the response of avocado to varying photon and $\mathrm{CO}_{2}$ fluxes was greater, $25 \%$ and $67 \%$, respectively, than for mango. These differences may be attributed to the contrast in leaf longevity between the two species. For many species the photosynthetic rate is negatively correlated to life span of the leaf, with deciduous species in general having higher net photosynthetic rates than evergreen species (Chabot and Hicks, 1982; Larcher, 1969). At the evolutionary level a hypothesis advanced to explain this phenomenon is "longer leaf life spans compensate for environmentally limited photosynthetic activity" (Chabot and Hicks, 1982). Compared to mango trees, the physiology of avocado trees more closely resembles that of woody deciduous species. There is comparatively little carbon investment into avocado leaves that grow rapidly but have a longevity of $<10$ months. In contrast, mango leaves are very sclerophyllous with a high investment of carbon during growth and are sustained on trees for up to 5 years (Whiley and Schaffer, 1994). While avocado was shown to have a greater capacity to respond to increased $C_{a}$, this may not necessarily result in greater yield as there is a higher carbon investment in fruit growth of this oil-rich crop compared with sugar-accumulating species such as mango (Wolstenholme, 1986, 1987).

\section{Literature Cited}

Arp, W.J. 1991. Effects of source-sink relations on photosynthetic acclimation to elevated $\mathrm{CO}_{2}$. Plant, Cell Environ. 14:869-875.

Björkman, O. 1987. Low temperature chlorophyll fluorescence in leaves and its relationship to photon yield of photosynthesis photoinhibition, p. 123-144. In: D.J. Kyle, C.B. Osmond, and C.J. Arntzen (eds.). Topics in photosynthesis. vol. 9. Elsevier Press, Amsterdam

Bower, J.P., B.N. Wolstenholme, and J.M. de Jagar. 1978. Incoming solar radiation and internal water status as stress factors in avocado, Persea americana Mill. cv. Edranol. Crop Prod. 7:129-133.

Chabot, B.F. and D.J. Hicks. 1982. The ecology of leaf life spans. Annu. Rev. Ecol. Syst. 13:229-259.

Chacko, E.K., P. Lu, and R.R. Kohli. 1995. Photoassimilate production and distribution in relation to productivity in mango (Mangifera indica), p. 109-124. In: Mango 2000Marketing seminar and production workshop proceedings. Queensland Dept. of Primary Ind., Brisbane.

Crane, J.H., C. Balerdi, R. Campbell, and S. Goldweber. 1994. Managing fruit orchards to minimize hurricane damage. HortTechnology 4:21-27.

Demmig, B. and O. Björkman. 1987. Comparison of the effect of excessive light on chlorophyll fluorescence (77k) and photon yield of $\mathrm{O}_{2}$ in leaves of higher plants. Planta
171:171-84.

Drake, B.G., M.A. Gonzàles-Meler, and S.P. Long. 1997. More efficient plants: A consequence of rising atmospheric $\mathrm{CO}_{2}$. Annu. Rev. Plant Physiol. Mol. Biol. 48:609-639.

Ehleringer, J. and O. Björkman. 1977. Quantum yields for $\mathrm{CO}_{2}$ uptake in $\mathrm{C}_{3}$ and $\mathrm{C}_{4}$ plants. Plant Physiol. 59:86-90.

Ehret, D.L. and P.A. Joliffe. 1985. Photosynthetic carbon dioxide exchange of bean plants grown at elevated carbon dioxide concentrations. Can. J. Bot. 63:2026-2030.

Groom, Q.J., N.R. Baker, and S.P. Long. 1991. Photoinhibition of holly (Ilex aquifolium) in the field during the winter. Physiol. Plant. 83:585-590.

Jones, H.G. 1992. Plant and the Microclimate. 2nd. ed. Cambridge Univ. Press, Cambridge.

Koch, K.E. 1996. Carbohydrate-modulated gene expression in plants. Annu. Rev. Plant Physiol. Plant Mol. Biol. 47:509-540.

Krause, G.G. 1988. Photoinhibition of photosynthesis. An evaluation of damaging and protective mechanisms. Physiol. Plant. 74:566-574.

Larson, K.D., B. Schaffer, and F.S. Davies. 1992. Flooding, mineral nutrition and gas exchange of mango trees. Scientia Hort. 52:113-124.

Larcher, W. 1969. The effect of environmental and physiological variables on the carbon dioxide gas exchange of trees. Photosynthetica 3:167-198.

Öquist, G. and R. Wass. 1988. A portable microprocessor operated instrument for measuring chlorophyll fluorescence kinetics in stress physiology. Physiol. Plant. 73:211-217.

Osman, A.M. and F.L. Milthorpe. 1971. Photosynthesis of wheat leaves in relation to leaf age, illuminance and nutrient supply. II. Results. Photosynthetica 5:61-68.

Peet, M.M. 1984. CO 2 enrichment of soybeans. Effects of leaf/pod ratio. Physiol. Plant. 60:38-42.

Pongsomboon, W., A.W. Whiley, R.A. Stephenson, and S. Subhabrabandhu. 1992. Effects of air temperatures on diurnal variation of water potential, conductance and $\mathrm{CO}_{2}$ assimilation of mango (Mangifera indica L.) leaves. Acta Hort. 321:472-481.

Powles, S.B. 1984. Photoinhibition of photosynthesis induced by visible light. Annu. Rev. Plant Physiol. 35:15-44.

Powles, S.B., J.A. Berry, and O. Björkman. 1983. Interaction between light and chilling temperature on the inhibition of photosynthesis in chilling-sensitive plants. Plant Cell Environ. 6:117-23.

Rasmussen, T.S. and R.J. Henry. 1990. Starch determination in horticultural plant material by an enzymatic colorimetric procedure. J. Sci. Food Agr. 53:159-170.

Schaffer, B. and P.C. Andersen. 1994. Introduction, p. 1-2. In: B. Schaffer and P.C. Andersen (eds.). Environmental physiology of fruit crops. vol. 2. Sub-tropical and tropical crops. CRC Press, Inc., Boca Raton, Fla.

Schaffer, B. and G.O. Gaye. 1989. Net gas exchange and chlorophyll and nitrogen content of mango leaves as influenced by developmental light environment. HortScience 24:507509.

Schaffer, B., L. Ramos, and S.P. Lara. 1987. Effect of fruit removal on net gas exchange of avocado leaves. HortScience 22:925-927.

Schaffer, B., C. Searle, A.W. Whiley, and R.J. Nissen. 1996. Effects of atmospheric CO enrichment and root restriction on leaf gas exchange and growth of banana (Musa). Physiol. Plant. 97:685-693.

Schaffer, B., A.W. Whiley, and J.H. Crane. 1994. Mango, p. 165-211. In: B. Schaffer and P.C. Andersen (eds.). Environmental physiology of fruit crops. vol. 2. Sub-tropical and tropical crops. CRC Press, Inc., Boca Raton, Fla.

Schaffer, B., A.W. Whiley, and R.R. Kholi. 1991. Effects of leaf age on gas exchange characteristics of avocado (Persea americana Mill.). Scientia Hort. 48:21-28.

Scholefield, P.B., J.J. Walcott, P.E. Kriedeman, and A. Ramadasan. 1980. Some environmental effects on photosynthesis and water relations of avocado leaves. Calif. Avocado Soc. Yrbk. 64:93-105

Searle, C., A.W. Whiley, D.R. Simpson, and J.B. Saranah. 1995. A preliminary phenophysiological model for 'Kensington' mango in subtropical Australia, p. 127-134. In: Mango 2000-Marketing seminar and production workshop proceedings. Queensland Dept. of Primary Ind., Brisbane.

Smillie, R.M., S.E. Hetherington, J. He, and R. Nott. 1988. Photoinhibition at chilling temperatures. Austral. J. Plant Physiol. 15:207-222.

Stitt, M. 1991. Rising $\mathrm{CO}_{2}$ levels and their potential significance for carbon flow in photosynthetic cells. Plant Cell Environ. 14:741-762.

Syvertsen, J.P. 1984. Light acclimation in citrus leaves. II. $\mathrm{CO}_{2}$ assimilation and light, water, and nitrogen use efficiency. J. Amer. Soc. Hort. Sci. 109:812-817.

Taylor, A.O. and J.A. Rowley. 1971. Plants under climatic stress. I. Low temperature, highlight effects on photosynthesis. Plant Physiol. 47:713-718.

Thomas, R.B. and B.R. Strain. 1991. Root restriction as a factor in photosynthetic acclimation of cotton seedlings grown in elevated carbon dioxide. Plant Physiol. 96:627-634.

Whiley, A.W. 1984. Crop management. Review paper, p. 186-195. In: Proc. 1st Austral. Mango Res. Wkshp., Cairns.

Whiley, A.W. 1994. Ecophysiological studies and tree manipulation for maximization of yield potential in avocado (Persea americana Mill.). PhD thesis, Univ. Natal, Pietermaritzburg, S. Afr.

Whiley, A.W. and B. Schaffer. 1994. Avocado, p. 3-35. In: B. Schaffer and P.C. Andersen (eds.). Environmental physiology of fruit crops. vol. 2. Sub-tropical and tropical crops. CRC Press Inc., Boca Raton, Fla.

Whiley, A.W., J.B. Saranah, B.W. Cull, and K.G. Pegg. 1988. Manage avocado tree growth cycles for productivity gains. Queensland Agr. J. 114:29-36.

Wolstenholme, B.N. 1986. Energy costs of fruiting as a yield-limiting factor with special reference to avocado. Acta Hort. 175:121-126.

Wolstenholme, B.N. 1987. Theoretical and applied aspects of avocado yield as affected by energy budgets and carbon partitioning. S. Afr. Avocado Growers' Assn. Yrbk. 10:58-61 